\title{
イヌにおける実験的腱板断裂修復
}

\author{
九州大学 整形外科 \\ 宮 原 寿 明・高 岸 憲 二 \\ 山口労災病院 整形外科 \\ 大 屋 国 益
}

\section{Experimental Repair of Rotator Cuff in the Dog}

by

\author{
Hisaaki Miyahara and Kenji Takagishi
}

Department of Orthopedic Surgery

Faculty of Medicine, Kyushu University

Kunimasu Ohya

Department of Orthopedic Surgery

Yamaguchi Rosai Hospital

The course of the repair of the rotator cuff rupture has not been fully clarified in comparison with that of other tendons. The purpose of this study is to deliniate the repair of the canine rotator cuff rupture histologically in two instances; 1) only resection of the rotator cuff tendon, 2) tendon to bone repair after cuff resection.

Twenty-four adult mongrel dogs $(12-17 \mathrm{~kg})$ were used. The study was divided into two groups: group I. Only resection of the rotator cuff; rotator cuff was resected $15 \mathrm{~mm}$ in width and $1 \mathrm{~mm}$ in length. Group II. Tendon to bone repair after cuff resection; the stump of the cuff was anchored into the trough cut at the greater tuberosity. After operation, a plaster cast was applied for three weeks. Dogs were killed at regular intervals and specimens including the cuff and the greater tuberosity were obtained. These were fixed, decalcified, embedded in paraffin, sectioned and stained with hematoxylin and eosin and with Malloryazan.

The gross and microscopic changes were investigated. Group I. After 1 week, scar tissue formation was present, but not completely, at the gap between the proximal stump and the greater tuberosity. After 2 weeks, the gap was completely filled with scar tissue. After 6 weeks, orientation of fibers was at randon with many proliferating vessels. Group II. After 2 weeks, orientation of the fibers were at random with proliferation of blood vessels. At the tendo-osseous junction, proliferation of cartilage tissue was noted. After 24 weeks, orientation of collagen fibers and appearance of tendo-osseous junction were similar to those seen in normal rotator cuff.

$$
\text { はじめに }
$$

手指屈筋腱やアキレス腱などの腱と比較して，腱板 の修復過程は充分には明らかとされていない，今回わ れわれはイヌを用いて腱板の部分的欠損を作製すると ともに，断端を骨溝に縫着し，修復過程を組織学的に 検討したので報告する。

\section{材料および方法}

体重15 kg から17 kg の雑種雄成犬24頭を用いた。 麻醉はケタラール筋注およびネンブタールの追加静注 とした．両肩において鎖骨上腕筋・三角筋間を展開し， 大結筋から斜後上方に走向する棘上筋腱を露出した.

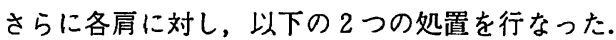


1)左局において棘上筋腱を大結節付着部にて線維方 向に巾 $15 \mathrm{~mm}$ ，長さ $10 \mathrm{~mm}$ にわたって切除，放置した。

2)右肩において同様の腱板切除後，大結節をノミで 切除し，海綿骨を露出させる．作製した骨溝に腱断端 を1号サージロン糸で縫合固定した。

術後，躯幹から上腕にかけて 3 週間ギプス固定を行 なった。切除群，修復群と甩術後 $1 \cdot 2 \cdot 3 \cdot 4 \cdot 6$ 週にて 2 頭ずつ屠殺し, 更に修復群のみ 12 週・24週を 作製した，屠殺後，棘上筋腓を大結節を含めて摘出し， ホルマリン固定, 脱灰後, 縦割標本を肉眼的に铔察, さらにH.E. および Azan-Mallory 染色を施して光顕 にて観察した。

\section{結果}

はじめに正常棘上筋肨および腱付着部の組織像を観 察した，表層の继線維は長軸方向に平行な配列を示す が, 媣層の配列はやや不規則であった. tendon to bone junctionにおいては, 1) tendon 2) fibrocartilage 3 ) calcified fibrocartilage 4) bone の 4 層が認めら れた.

次に各週における腱板切除および修復後の所見をの ベる.

健板切除 1 週: 肉眼的に腱板切除部は般痕様組織で おおわれていたため, 標本摘出前, メチレン・ブルー 約 $3 \mathrm{cc}$ を関節内に注入してみたが，漏出はみられな

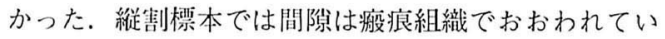
た. 組織所見で間隙は線維性結合組織でつながるとと もに，出血策，炎症細胞の浸潤がみられた。腱断端の 線維は染色性が低下し，浮腫状を呈した。

揵板修復 1 週: 縦割標本で揵は骨溝に固定されてい た. 組織所見では继断端の変性, fibroblast の增生 お よび脠内への浸潤，出血巣，炎症細胞の浸潤を認めた。 切骨部には empty lacuna が認められ，破骨細胞が散 在していた.

腱板切除 2 週: 組織所見で間隙はほとんど結合組織 で満たされており, fibroblast の増生と出血巣，炎症 細胞の浸潤がみられた。結合組織の配列は不規則であ った. 腱断端の変性は更に進み, 染色性は低下し, myxomatous となった（図1).

腱板修復 2 週 : 組織像では腱断端における fibroblast の增生がさらに著明となり，不規則な線維配列の 中に出血巣の残存, 新生血管の増殖，炎症細胞の浸潤
を認めた. tendon to bone junction においては軟骨細 胞の集簇性出現を認めた（図 2 ).

$3 \sim 4$ 週では切除群, 修復群とも fibroblast の増生 が更に進み, 再構筑の進行がみられた。

涎板切除 6 週：組織では線維の走向はまだ不規則で あり，血管増生も残存していた。

腱板修復 6 週 : 組織では線維の走向はやや不規則で,

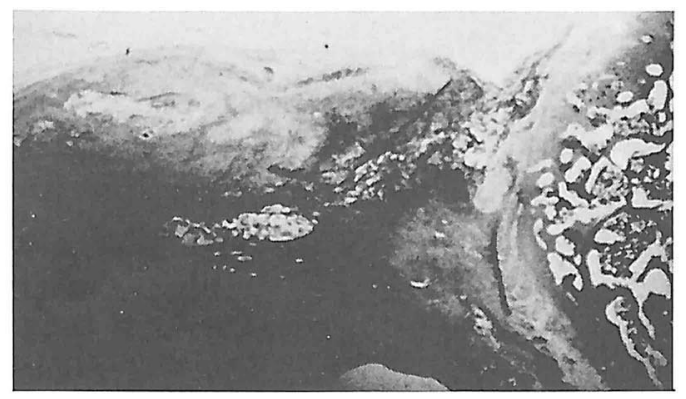

図 1 陫板切除 2 週. 涎断端 (A) と大結節上縁 (B) との間隙は旅痕組織で满たされている.

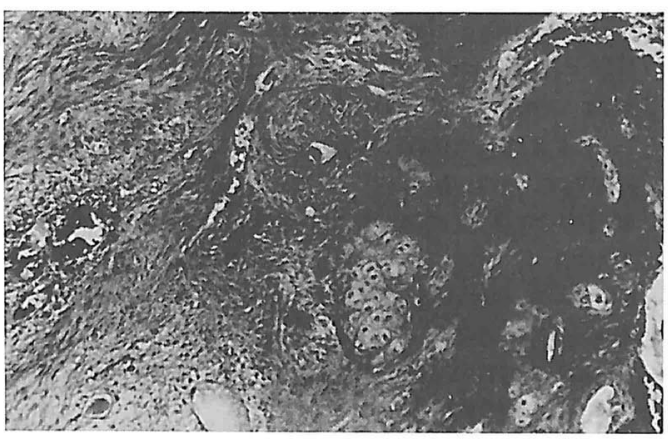

図 2 涏板修復 2 週. 中央右に tendon to bone junctionにおける軟骨細胞の集簇性出現をみる.

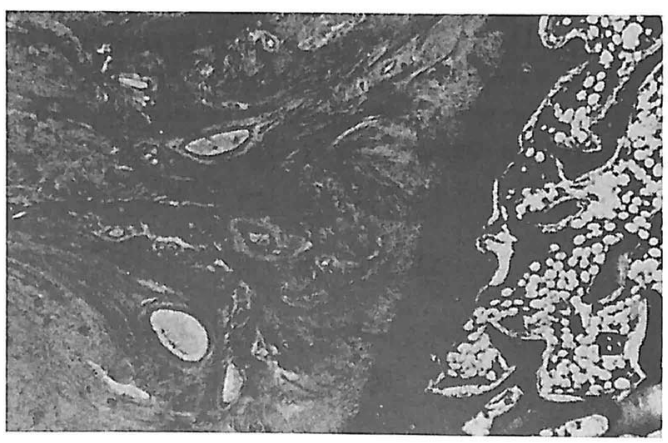

図 3 腱板修復24週. tendon to bone junction では正 常腱付着部に類似した 4 層形成を認める. 
血管はまだ残存し, tendon to bone junction では軟骨 細胞が長軸方向に配列してきた.

腱板修復24週では tendon to bone junction の4層形 成は不充分だが, 正常腱付着部に類似していた（図3).

\section{考察}

腱板断裂の手術法として McLaughlin 法”の如く,腱 断端を骨溝に縫着する方法が広く用いられているが， その修復過程は明らかではない. われわれはイヌにお いて腱板の手術的欠損を作製し，切除後放置したもの (切除群) および腱断端を骨溝に縫着したもの（修復 群）の 2 群に分けて, それぞれの組織学的修復過程を 観察した.

切除群において, 術後 1 週の早期より㿂痕組織によ る癒合がみられ，メチレンブルーの関節内注入による 関節外への色素の漏出は認められなかった.これは, ヒトと違ってイヌでは大結節と肩峰が離れており, impingement をきたさないために健の変性をきたさない こと，および人為的に腱板断裂をきたしたことによっ ておこったと思われる. また，イヌとヒトとの種の相 違, さらには加令による変性が少ないこと等も関連し ていると思われる.

修復群においては, 術後 1 ～ 2 週で健断端の変性, 炎症細胞浸潤とともに新生血管, fibroblast $の$ 増生が おこった. また切骨部骨壁では骨壊死と破骨細胞の出現 がおこり，軟骨細胞の集簇性出現とあいまって，いわ ゆる内軟骨性仮骨の形成が認められた。週数を経るに したがい, 変性腓断端部に fibroblast の増生をともな つた collagen fiber の再生, 並行配列化がおこるとと もに, tendon to bone junction において再構築が進み,

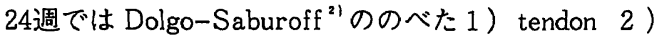
fibrocartilage 3) calcified fibrocartilage 4) bone の 4 つの層が不充分だが認められ，ほぼ正常腱付着部 と類似した像を認める事ができた.

これらの所見は，修復の経過に時間的相違はあるも のの，他部位の腱ないし靶帯を用いた実験 ${ }^{(3 / 5)}$ で報告 されている所見とほぼ同様であり，骨への強固な anchoring が期待され得るものと考えられる. 今後, さ らに microangiography および biomechanics などの手 法を用いて検討する必要がある.

$$
\text { ま と め }
$$

1）イヌを用いて腱板の部分的欠損を作製するととも に，断端を骨湷に縫着し，修復過程を組織学的に 調べた.

2) 腱板切除群では 1 週より撚瘦性に修復がおこり, 断裂を持続させ得なかった，種の相違，加令によ る変性が少ない, 解剖学上 impingement をきたさ ない等の要因が考えられた。

3) 腱板修復群では経過とともに tendon to bone junction の再樁築がおこり，24週では組織学的に正常 に類似した像を呈した。

\section{参 考 文 献}

1) Clancy, W.G.: Anterior and posterior cruciate ligament reconstruction in rhesus monkeys. J.B.J.S., 63-A : 1270-1284, 1981.

2) Dolgo-Saburoff, B.: Uber Ursprung und Insertion der Skelettmuskeln. Anat. Anz., 68:30-87, 19 29.

3) Forward, A.D.: Tendon suture to bone. J.B.J.S., 45-A : 807-823, 1963.

4) McLaughlin, H.L.: Lesions of the musculotendinous cuff of the shoulder 1 . The exposure and treatment of tears with retraction. J.B.J.S. $26: 31$ $-51,1944$.

5) Whiston, T.B.: Some observations on the reaction of bone and tendon after tunneling of bone and insertion of tendon. J.B.J.S. 42-B :377-386, 1960.

\section{質 問産業医科大学 小林 靖幸} 組織学的には正常に類似した所見が25週目では得ら れるとのことですが，その時の肉眼的所見は如何だっ たでしょうか?

肉眼的には tendon to bone junction の部位は菲薄化 しているかあるいは肥厚しているのでしょうか.

\section{解 答山口労災病院 宮原 寿明}

術後早期の数週においては，腱板に隣接する滑膜， 滑液包の肥厚がみられる.これは24週後には減少を示 した. 